\title{
Codes of Practice for the Mental Health Acts, England and Wales/Scotland
}

The meeting of the Public Policy Committee in November 1990 suggested that it would be helpful to highlight briefly the differences between the English and Scottish Codes of Practice to the relevant Mental Health Acts. There are, broadly speaking, two major areas of difference which in turn lead to some of the more detailed points of difference.

The first lies in the style of the two documents. The Scottish Code is essentially a series of broad general principles underlying the implementation of the Act. As such, it does not go into great detail about the procedures involved in implementing the various sections of the Act although it does occasionally contain points of practical detail, e.g. paragraphs 1.24 and 1.25 which specifically refer to the services of an interpreter when dealing with persons of foreign nationality or someone with relevant communication skills when dealing with the profoundly deaf. In contrast, the English Code goes into considerably more detail in many of its sections, for example in specifying precisely which doctors, social workers etc, should be involved, the roles of hospital managers etc. and the step by step procedures to be carried out.

The second major difference between the Scottish and English Codes is their length. At first sight, the English Code contains many sections which are omitted from the Scottish Code. However, there is in fact a fairly simple explanation for many of these differences between the two Codes, and that is that in Scotland there was issued, in 1986, a very detailed set of Notes on Act running to 167 pages and 450 para- graphs. The Scottish Notes of Guidance, of course, parallel the English Memorandum to the Act. Many of the paragraphs of guidance contained in the English Code are mirrored by similar, sometimes lengthy, sections in the Scottish Notes of Guidance. Appendix A attempts to explain this by setting out the index of the English Code and then listing alongside it the paragraphs in the Scottish Code and/or the Scottish Notes of Guidance which contain broadly the same information. It will thus be seen that the bulk of what is contained in the English Code appears either in the Scottish Code, often in a much abbreviated form, or else, in more detail, in the Scottish Notes of Guidance.

There are, however, a number of major differences. The Scottish Code makes no reference to Guardianship. This is alluded to in the circular which was issued with the Code, and which is actually bound in it, but the main set of guidance on Guardianshipis contained in the Notes of Guidance. There is no specific reference in either of the Scottish documents to Patients Presenting Particular Management Problems, Complaints, Personal Searches, or People with Mental Handicap.

The full Contents pages of the Scottish Notes of Guidance illustrating the range of topics that these Notes cover can be obtained from Deborah Hart at the College.

P. W. BRoOKs Approved by the Executive and Finance Committee, January 1991.

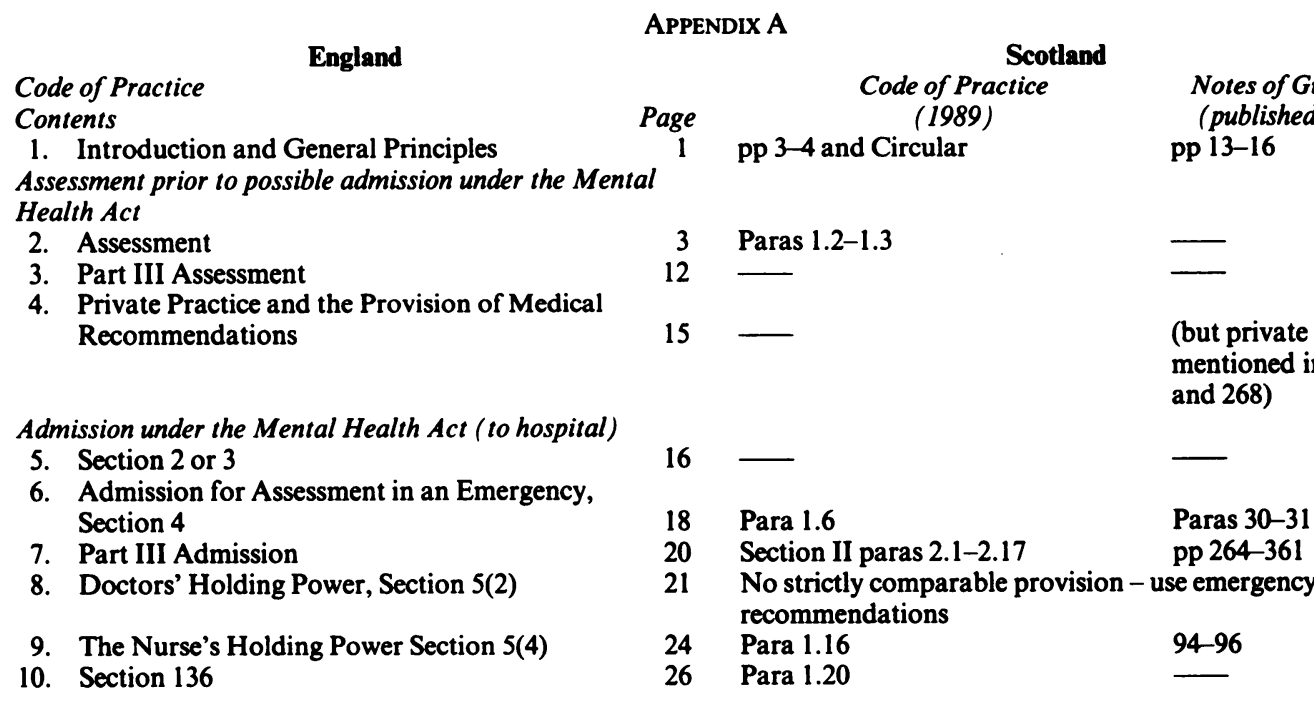




\begin{tabular}{|c|c|c|c|}
\hline APPEl & NDIX A & (Continued) & \\
\hline England & & Scot & \\
\hline Code of Practice & & Code of Practice & Notes of Guidance \\
\hline Contents & Page & & (published 1986) \\
\hline 11. Conveying to Hospital & 30 & Para 1.10 & $51-52$ \\
\hline 12. Receipt and Scrutiny of Documents & 32 & & 9 and 55 \\
\hline Admission under the Mental Health Act (to guardiansh & & & \\
\hline $\begin{array}{l}\text { 13. Guardianship } \\
\text { Treatment and care in hospital }\end{array}$ & 34 & - & pp 187-263 \\
\hline 14. Information & 37 & Para $1.21-1.22$ & Paras 440-446 \\
\hline 15. Medical Treatment & 41 & Section IV paras 4.1-4.11 & Paras 382-397 \\
\hline 16. Medical Treatment and Second Opinions & 49 & Annex from MWC & \\
\hline 17. Part III. Medical Treatment for Mental Disorde & 58 & Para 2.15 & \\
\hline $\begin{array}{l}\text { 18. Patients Presenting Particular Management } \\
\text { Problems }\end{array}$ & & & \\
\hline 19. Psychological Treatments & 67 & Para 4.8 & \\
\hline 20. Leave of Absence, Section 17 & 69 & Para 3.6 & Paras 110-119 \\
\hline 21. Absconding Patients, Sections 18,137 and 138 & 71 & - & Paras $120-125$ \\
\hline Managers Duty to Review Detention & 72 & - & Paras 206-209 \\
\hline 23. Complaints & 74 & - & \\
\hline 24. Duties of the Hospital Managers & 75 & Paras 1.21-1.22 & $\begin{array}{l}\text { Referred to in } \\
\text { previous para }\end{array}$ \\
\hline $\begin{array}{l}\text { 25. Personal Searches } \\
\text { Leaving hospital }\end{array}$ & 77 & - & - \\
\hline $\begin{array}{l}\text { 26. After Care } \\
\text { 27. Part III. Leaving Hospital }\end{array}$ & $\begin{array}{l}78 \\
81\end{array}$ & Section II 3.1-3.8 & Paras 171-186 \\
\hline Particular groups of patients & & & \\
\hline 28. People with Mental Handicap & 83 & - & - \\
\hline 29. Children & 85 & - & Para 4 \\
\hline
\end{tabular}

Psychiatric Bulletin (1991), 15, 312

\section{Achieving a Balance-Plan for Action}

\section{Rotational training schemes}

The movement of registrars' contracts to regional health authorities, and the requirement that registrars are appointed by an appointments committee, the constitution of which is determined by the Department of Health, do not necessitate the dismantling of SHO-registrar rotational training schemes. However, in some regions dis-association of SHO and registrar training may be beneficial in relation to the quality of general professional training that can be provided to each group, also bearing in mind the requirements of vocational trainees for general practice.

Schemes' approval status with the College must not be jeopardised, which may occur if changes are made, or imposed, without appropriate consultation.

The Central Approval Panel has decided, with endorsement by the Court of Electors, that proposed administrative changes to schemes should be discussed with the Convener responsible for the Division of the College where the scheme is located, who may wish to make a short visit to gain understanding of the situation. Additionally, training schemes which are being amalgamated will still be visited on the due date, when again local developments can be monitored.
Names of Convenors and dates that visits to schemes are due can be obtained from Jane Hinton, Deputy Education Officer, at the College.

\section{'The safety net'}

This refers to intermediate cover, i.e. between first on-call and the responsible consultant. It is unlikely that this is relevant to many psychiatric services where normally a SHO or registrar is on-call, covered by a consultant. Senior registrars may act for a named consultant, as second on-call, as approved by the JCHPT.

The term 'safety net' applies, in psychiatry, when a SHO or registrar has a more experienced trainee (registrar or senior registrar) available on-call providing an intermediate tier between him or her and the responsible consultant.

I appreciate that Members and Fellows have many concerns about the implementation of Achieving $a$ Balance - Plan for Action and hope that they will not hesitate to contact me at the College if the Education Department can be of assistance in this regard.

Dr Fiona Caldicott Dean 